

\title{
Phreatophyte Research in the Western States March 1959 to July 1964
}

\author{
By T. W. Robinson
}

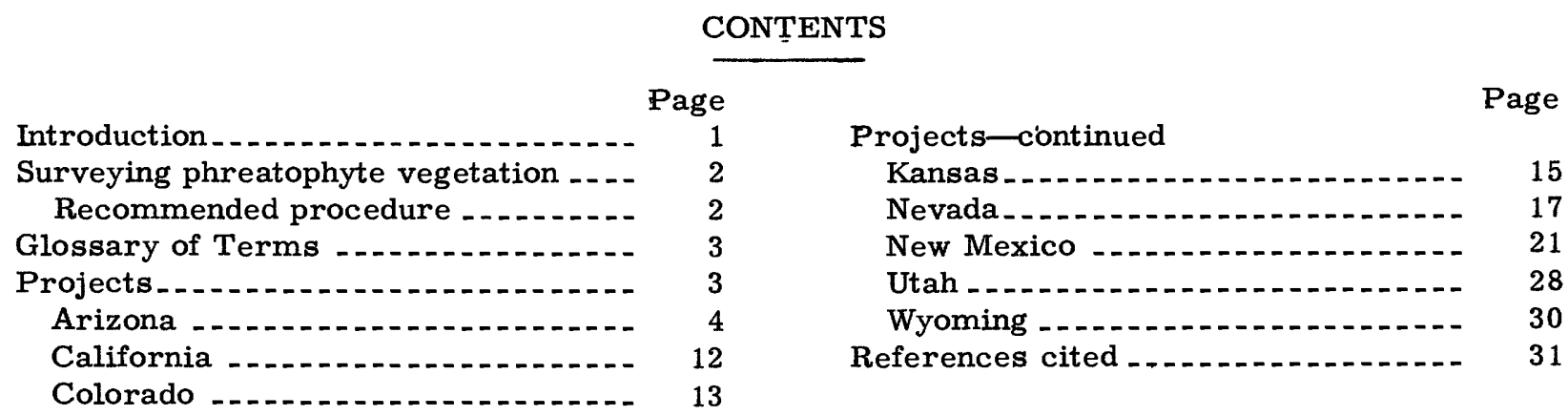

INTRODUCTION

In the arid and semiarid regions of the Western States phreatophytes waste more than 25 million acre-feet of water into the atmosphere annually (Robinson, 1952). Phreatophytes, plants that depend upon ground water for their water supply, have a direct root connection with the water table. During the growing season they satisfy their needs for water by drawing on the ground-water reservoir, somewhat like a pump. In fact each plant may be considered as a miniature pumping plant operating at varying rates according to the needs of the plants. The withdrawals of water deplete the ground-water reservoir, with the result that ground-water levels are lowered.

Phreatophytes grow largely, although not entirely, along the banks of streams, in their flood plains, and in the delta areas at the heads of reservoirs. Here the ground-water reservoir has a direct connection with the water in the stream, such that streamflow reflects the effect of the draft on the groundwater reservoir. As the draft increases, there is a reduction in the streamflow, and, as a consequence, in the water that is readily available for man's use.
The economic value of most phreatophytes is low, and the water used by them is largely wasted. Water use in this way is known as nonbeneficial consumptive use and more recently has been referred to as consumptive waste (Robinson, 1958). Ground water that is consumptively wasted by phreatophytes is available for salvage. Salvage, as applied to the phreatophyte problem, is converting consumptive waste to beneficial consumptive use.

In order to plan a salvage project, infor mation is needed concerning (1) the magnitude of the consumptive waste, (2) the method of effecting salvage, and (3) the economic feasibility. Determination of the magnitude of the consumptive waste involves a knowledge of the species growing in the project area, their cover density and height, and the climatic and hydrologic conditions. The methods of salvage must be evaluated in order to select the one with the greatest promise. The three general methods are: (1) Taking the plants away from the water (eradication, of which there are several ways), (2) taking the water away from the plants (here again there are several ways), and (3) substituting plants of higher beneficial use in the project area. 
In the final analysis salvage is an economic problem. Thus, any salvage project should have a favorable cost-benefit ratio. Each of the research and control projects described in this report is concerned with one or more of the many facets that make up the phreatophyte problem.

In early 1958, the Phreatophyte Subcommittee of the Pacific Southwest Inter-Agency Committee recognized the need for assembling information on current research studies and making this information public. As a result U.S. Geological Survey Circular 413, "Phreatophyte Research in Western United States, October 1958 to March 1959," was prepared (Robinson, 1959). In the 5 years that have elapsed since the publication of this report, there have been many changes. A few projects have been completed, a number of new ones started, and some are still in progress. As it is the subcommittee's responsibility to keep abreast of developments that concern phreatophytes and to keep the parent committee informed of these developments, the subcommittee at its $63-4$ meeting decided to bring the information up to date. The responsibility for this updating, as well as the original report, was assigned to the author as chairman of the task force on research and coordination.

The phreatophyte problem is being studied by different Federal and State agencies and by departments in some universities. The scope and objectives of most studies are known to the subcommitte, but only in a general way. In order to have more comprehensive coverage, the representatives and project leaders of all agencies or departments known or believed to be studying the phreatophyte problem were contacted and asked to supply a description, the status, and plans for publication for projects in progress in the period March 1959 to July 1964.

The phreatophyte problem has many facets. Basically the research necessary to solve the problem may be divided into three general categories: Hydrologic and ecologic, eradication and control, and water salvage. These fields of research cover such a wide spectrum that it would be difficult for one individual to pursue all of them. Fortunately, they may be treated separately even though in the final analysis and solution they are dependent one on the other (Pacific Southwest Inter-Agency Committee, 1961).

\section{SURVEYING PHREATOPHYTE VEGETATION}

As noted earlier, a knowledge of the kinds and amounts of vegetation is a prerequisite to the preparation of plans for any watersalvage undertaking. In this connection, it is highly desirable to standardize procedures for surveying and mapping phreatophytes. In recognition of these facts, the Phreatophyte Subcommittee of the Pacific Southwest InterAgency Committee organized a task force to to develop standard methods. The work of the task force, which began in 1956, was completed in May 1964 with the publication of a handbook entitled "Guide for Surveying Phreatophyte Vegetation" (Horton, Robinson, and McDonald, 1964).

\section{RECOMMENDED PROCEDURE}

The handbook presents a survey procedure, based upon random sampling, that can be tested for statistical reliability. It is concerned principally with surveys designed to collect information that can be used as a basis for project planning in connection with watersalvage operations.

The procedure outlined for phreatophyte surveys is based upon determination of crown cover, height of trees and shrubs, and depth of crown by use of randomly selected sampling lines. The statistical procedures are based upon estimation of crown cover within prescribed limits of precision. Height of trees and shrubs and depth of crown are obtained from survey data, but no estimates of precision for these data are attempted.

Seven steps suggested for a survey of phreatophyte vegetation are:

1. Determine the area to be surveyed and the necessary area breakdowns. Assemble aerial photographs for the entire survey area, and familiarize all workers with the species and vegetation types involved.

2. Prepare, in the office, preliminary vegetation maps of the survey area from aerial photographs, with later refinements of type boundaries by observation from aircraft.

3. Determine number of sampling lines needed to achieve desired precision by a preliminary field survey and by applying the data to a nomograph.

4. Develop a sampling system with random selection of the sampling lines. 
5. Collect field data from the randomly selected sampling lines, and permanently mark these lines for future surveys.

6. Determine reliability of the field data by use of standard statistical methods.

7. Summarize the data in a form best suited to achieve the purposes of the study.

\section{GLOSSARY OF TERMS}

Members of the Phreatophyte Subcommittee, in considering phreatophyte problems, gradually became aware that there were differences of opinions as to the meaning of terms used in discussing the problems. In order to avoid misunderstanding and to provide a standard of reference, the subcommittee appointed a task force, of which the author was chairman, to develop a glossary of terms that would be applicable.

After $1 \frac{1}{2}$ years of study and work by the task force and three reviews by the subcommittee as a whole, such a glossary was developed. In November 1962, a report entitled "Glossary of Terms Relating to the Phreatophyte Problem" was mimeographed and dis tributed to members of the subcommittee and to others interested in the problem. It is tentatively planned that the glossary will be published in one of the numbered series of reports by the Geological Survey in 1964 or 1965.

\section{PROJECTS}

In order that the information may be uniform and comparable, each project description follows the outline used in Circular 413 (Robinson, 1959), which is:

Title of project.

Agency or department; if a cooperative project, all cooperating parties are shown.

Project leader; the person actively and directly in charge of project.

Description of project; a brief and concise summary, giving the general work plan and objectives.

Present status.

Results.

Publication plans.

The author is indebted to project leaders and agency representatives who prepared the project descriptions. Without their cooperation and wholehearted support the coverage of this report would not have been possible.
Each project in this report has been assigned a number, identifying it with the State in which the project is located. These numbers, preceded by the abbreviation for the State, run consecutively. They have no identifying relation to the project and are for reference only. In order to provide a cross reference for those projects that were given in Circular 413 also, the number in the circular is shown in parentheses below the project number thus:

$$
\text { (1, Ariz-1 } 4 \text { - } 13 \text { ) }
$$

The projects are grouped by States in alphabetical order. Every effort was made to include all projects currently underway; but if any have been omitted, it is because they were not brought to the author's attention.

A total of 48 projects is described. This is an increase of 100 percent over the 24 described in Circular 413. Following is their distribution by States:
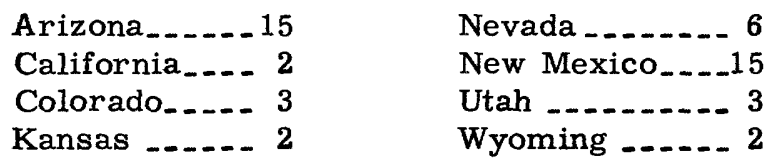

Of the 24 projects listed in Circular 413 , 10 have been completed, 6 are inactive, and 8 were active as of July 1, 1964. Eighteen agencies participated in the 24 projects. Several agencies were concerned with two or more projects, so that in all there were 48 agency-project participations.

Of the 48 projects listed in this report, 6 were inactive as of July 1, 1964. Here also there was participation by two or more agencies in most of the projects, with an overall total of 90 agency-project participations. The following tabulation shows the participation in projects by agencies.

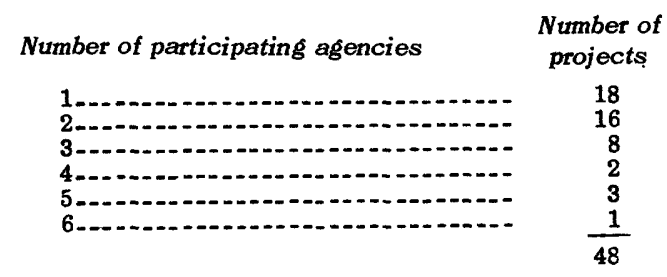

Nine agencies with a total of 60 agencyproject participations were Federal, and 21 
agencies with 33 agency-project participations were State or local agencies or an individual. The names of the agencies, together with the number of projects in which they were participating, are given in the following listing.

List of agencies and their project participations FEDERAL AGENCIES

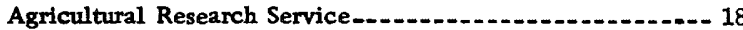

Corps of Engineers

Bureau of Indian Affairs .

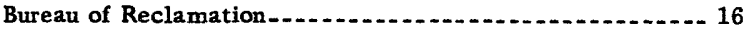

Bureau of Sport Fisheries ...

Forest Service -...

Geological Survey

Soil Conservation Service _..........

Weather Bureau ........

STATE AND LOCAL AGENCIES AND INDIVIDUALS

Arizona Land and Water Department ....................... 1

Salt River Water Users Association.....................

San Carlos Apache Tribe - . . . . .

University of Arizona

California Department of Water Resources .................... 1

Colorado State University-_..............

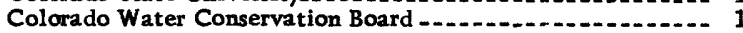

Fort Hays Kansas State College

Nevada Agricultural Experiment Station ......................-

Nevada Department of Conservation and Natural Resources.- 2

New Mexico Agricultural Experiment Station................ 4

New Mexico State Engineer..........................

New Mexico State University-_._._.

A. P. Atkins, rancher …

Pecos River Commission ................................... 1

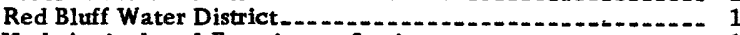

Utah Agricultural Experiment Station _................ 1

Utah State Engineer - _._.........

Utah Water and Power Board .............................. 1

Wyoming Agricultural Experiment Station ........ 2

The findings that result from a research project are commonly described in a report or, in some cases, a series of reports covering different phases of the project. The number and quality of the reports are a measure of the progress and of the importance of the study. From a review of the 48 project descriptions that follow, it was found that 61 reports have been prepared in one form or another. A few reports are primarily for internal use of the agency sponsoring the study, some are mimographed or duplicated reports, others are articles published in technical journals, and still others are published separately in book or pamphlet form as part of a numbered series. Copies of most of the reports may be obtained from the project leader.

\section{ARIZONA}

Ariz-1

(1, Circ. 413)

Title

Effects of clearing phreatophytes from stream channels.

\section{Agencies}

University of Arizona, U.S. Bureau of Reclamation, and U.S. Corps of Engineers.

\section{Leaders}

K. R. Frost and K. C. Hamilton, University of Arizona.

\section{Description}

In the interest of water conservation and flood protection, a 400-foot-wide strip of river-bottom vegetation was cleared by the Wellton-Mohawk Irrigation and Drainage District along the-channel of the Gila River from Texas Hill to Dome, Ariz., a distance of 55 miles. The vegetation consisted largely of saltcedar, with lesser amounts of mesquite, saltbush, and baccharis. Clearing operations, using bulldozers equipped with a cutter knife for cutting below the root crown, were begun in the spring of 1958 and completed that growing season.

The objectives of the project are to obtain data and information on: (1) the effectiveness of mechanical methods for controlling salt cedar and other river-bottom vegetation, (2) cost of clearing, (3) plant succession following clearing, (4) effect of clearing on the quantity and quality of the ground water, and (5) effectiveness of methods for maintaining cleared channels.

In order to obtain the desired information, 96 plots, each 20 feet by 100 feet, were established in or adjacent to the cleared area for the purpose of measuring the tree cover and density, and the height, basal diameter, and spread of the trees. Eleven wells were constructed for use in obtaining ground-water levels and water samples. Clearing cost data were obtained for various locations of different plant density.

\section{Status}

\section{Completed.}

\section{Results}

Plant density was found to range from 24 to 63 percent. Clearing operations reduced plant density 90 percent and plant cover 99 percent. Operation costs for undercutting ranged from $\$ 6$ per acre for densities of 20 to 30 percent to $\$ 30$ per acre for densities of 80 to 90 percent; average, about $\$ 15$ per acre. 
Water levels rose slightly following clearing, and there was an increase in the electrical conductivity of the ground water.

\section{Publications}

Progress report in Pacific Southwest InterAgency Committee minutes of 58-4 meeting at Las Vegas, Nev., Dec. 3, 1958, as Attachment $K$ of the Phreatophyte Subcommittee minutes.

Report on the Wellton-Mohawk salt cedar clearing studies, by K. R. Frost and K. C. Hamilton: Agr. Exp. Sta., Univ. of Arizona, Tucson, Rept. 193, Nov. 1960.

$$
\text { Ariz-2 }
$$

(2, Circ. 413)

Title

Use of water by riparian vegetation in Cottonwood Wash, Arizona.

\section{Agencies}

U.S. Geological Survey, Arizona State Land Department, Salt River Valley Water Users' Association.

\section{Leader}

James E. Bowie, U.S. Geological Survey.

\section{Description}

Water savings by modification of riparian vegetation were measured in Cottonwood Wash, Mohave County, Ariz. A 4.1-mile reach of the channel was selected and divided into a 2.6-mile upper reach and a 1.5-mile lower reach. Measurements of streamflow, groundwater levels, vegetation, and meteorological phenomena obtained in the entire reach defined the use of water by riparian vegetation under natural hydrologic conditions. Subsequent defoliation and eradication of the vegetation in the lower reach permitted the determination of the change in water use as a result of the modification.

The principal types of vegetation include Fremont cottonwood, red willow, velvet ash, and seep willow. The total volume of foliage in both reaches was 154.8 acre-feet. The volume of foliage in the lower reach was about 69.8 acre-feet. The defoliation of this reach was accomplished by spraying with magesium chlorate. The eradication was ac- complished by either cutting or frilling the trees and then poisoning with Ammate $X$ in crystal form. Brush was cut or poisoned. The poison used for this phase was Ammate $\mathrm{X}$ in solution.

Status

Completed.

Results

The computed average loss in the lower reach before modification was 80 acre-feet per growing season, which represented about 18 percent of the average flow entering the reach. The average loss after modification was 42 acre-feet per growing season, which represented about 12 percent of the average flow entering the reach.

\section{Publication}

U.S. Geological Survey Water-Supply Paper (manuscript to go to colleague review).

Ariz-3

(3, Circ. 413)

Title

Life history of tamarisk and related phreatophytes.

\section{Agency}

U.S. Forest Service, Rocky Mountain Forest and Range Experiment Station.

Leader

Jerome S. Horton.

\section{Description}

A careful management of vegetation will be necessary to salvage additional water from the phreatophyte zone. Basic information concerning the life history of the principal species is necessary before a management practice can be applied with any assurance that the desired vegetation can be maintained and that undesirable species will not reinvade. Project covers the taxonomy and anatomy of the principal species and the influence of site and climatic factors upon seed germination, seedling establishment, phenological response, and individual growth and development (including roots). 
Status

Some phases, such as the seed-germination and anatomy studies, are nearing completion; others will require several more years.

\section{Results}

Tamarisk seeds germinate very readily when moist, but the surviving seedlings require continuously wet soil for several weeks. This fact indicates that control of overflow would prevent invasion of tamarisk. Cuttings of tamarisk sprout vigorously when partially covered with warm moist soil but lose sprouting ability very quickly when dried for short periods of time. Thus, mechanical clearing should be accomplished when the soils are dry and the weather warm.

Studies have shown that Tamarix pentandra Pall. is the abundant species in the Southwest and that T. gallica L. has become aggressively naturalized only in the humid areas around the Gulf of Mexico.

\section{Publications}

Seed germination and seedling establishment of phreatophyte species, by J. S. Horton, F. C. Mounts and J. M. Kraft: Rocky Mtn. Forest and Range Expt. Sta. Paper 48, 26 p., illus., 1960.

The problem of phreatophytes, by J. S. Horton: Symposium of Hannoversch-Munden, Internat. Sci. Hydrol. Assoc. Pub. 48(1), p. 76-83, 1959.

Salt secretion by Tamarix pentandra by J. P. Decker: Forest Sci. 7(3), p. 214-217, 1961.

Root distribution of five-stamen tamarisk, seepwillow, and arrowweed, by H. L. Gary: Forest Sci. 9(3), p. 311-314, 1963.

Notes on the introduction of deciduous tamarisk, by J. S. Horton: Rocky Mtn. Forest and Range Expt. Sta., Forest Service Research Note RM-16, 7 p., 1964.

Taxonomic notes on Tamarix pentandra in Arizona, by J. S. Horton and J. E. Flood: Southwestern Naturalist 7, p. 23-28, 1962.

$$
\text { Ariz-4 }
$$

(4, Circ. 413)

Title

Development of survey methods for phreatophyte and riparian associations.
Agency

U.S. Forest Service, Rocky Mountain Forest and Range Experiment Station.

Leaders

C. J. Campbell and J. S. Horton.

\section{Description}

A survey of the occurrence and characteristics of the phreatophyte zone is needed in the Southwest, both for the phreatophytedominated flood plains and the riparian vegetation along mountain streams. Methods for surveying vegetation of these types are not well developed. Through the auspices of the Phreatophyte Subcommittee, existing methods of measuring woody vegetation were evaluated.

A method of field reconnaissance survey is being developed to provide a relatively fast and accurate sampling technique for measuring riparian vegetation. The survey is designed to test the value of aerial photography in mapping inaccessible riparian vegetation.

\section{Status}

An extensive ground survey is being made with the intention of later comparing the survey data with information obtained from largescale aerial photographs (to be taken in the summer of 1964). The ground survey is about three-fourths completed.

\section{Results}

Total cover based on the average of ocular estimates in Sycamore Creek in Arizona tends to increase with elevation from 37 percent at the lowest 5 -mile reach to $29,56,45$, and 66 percent, respectively, in the next four 5-mile reaches. Some species exist only at the lower elevations, while others are limited to the middle or upper reaches.

\section{Publication}

Guide for surveying phreatophyte vegetation, by J. S. Horton, T. W. Robinson, and H. R. McDonald: U.S. Dept. of Agriculture, Forest Service, Agriculture Handb. 266, 37 p., illus., 1964 .

$$
\text { Ariz -5 }
$$

$$
\text { (5, Circ. 413) }
$$

\section{Title}

Development of equipment for measuring evapotranspiration of undisturbed vegetation. 
Agency

U.S. Forest Service, Rocky Mountain Forest and Range Experiment Station.

\section{Leader}

Richard Lee.

\section{Description}

As a basis for management of streambanks and flood plains to reduce water losses by phreatophytes, information is needed as to the amount of water that would be lost from a given area of land if it were occupied by different types of plant communities. This requires an apparatus that can measure accurately water losses from individual plants or segments of plant cover.

Status

Inactive.

Results

An evapotranspiration tent apparatus has been developed by J. P. Decker and has been successfully used to measure vapor changes from transpiring shrubs up to 10 feet in height. Correlation exists between the heat pulse velocity meter (sap flow) and the evapotranspiration tent data.

\section{Publications}

Transpiration surges in Tamarix and Eucalyp tus as measured with infrared gas analyzer, by J. P. Decker and J. D. Wien: Plant Physiology 35(3), p. 340-343, 1960.

Simultaneous studies of transpiration rate and sap velocity in trees, by J. P. Decker and C. M. Skau: Plant Physiology 39(2), p. 213-215, 1964.

$$
\begin{gathered}
\text { Ariz-6 } \\
\text { (6, Circ. 413) }
\end{gathered}
$$

Title

Measurement of evapotranspiration. Agency

U.S. Forest Service, Rocky Mountain Forest and Range Experiment Station.

\section{Leader}

Richard Lee.

Description

In order to determine water losses from the different phreatophyte covers and, there- fore, to determine which are desirable to maintain or to establish, evapotranspiration losses must be measured over a wide variety of conditions. These measurements should be made precisely, to determine losses from individual plants or small areas, by evapotranspiration tents and lysimeters or by gross measurements such as those from transpiration wells and stream-gaging stations.

\section{Status}

Transpiration wells have been established in an experimental area along the Salt River above Granite Reef Dam. The evapotranspiration tent's effect on the microclimate is being studied with close cooperation between the U.S. Forest Service, University of Arizona, and the U.S. Bureau of Reclamation.

Results

The indications are that tamarisk uses more water than a bermudagrass sod. Transpiration wells did not give reliable data and, therefore, have been discontinued.

\section{Publications}

Measuring transpiration of undisturbed tamarisk shrubs, by J. P. Decker, W. G. Gaylord, and F. D. Cole: Plant Physiology 37(3), p. 393-397, 1962.

Removal of tamarisk reduced water-table fluctuations in central Arizona, by H. L. Gary: Rocky Mtn. Forest and Range Expt. Sta. Research Note 81, 1962 .

An analysis and simplification of the Blaney-Criddle method for estimating evapotranspiration, by J. P. Decker: U.S. Forest Service, Rocky Mtn. Forest and Range Expt. Sta. Research Note RM-2, 2 p., 1963.

$$
\text { (7, Circ. 413) }
$$

Title

Replacement of undesirable vegetation.

\section{Agency}

U.S. Forest Service, Rocky Mountain Forest and Range Experiment Station.

\section{Leader}

J. S. Horton. 


\section{Description}

After it is determined that an existing phreatophyte stand is undesirable, a more desirable type of cover must be selected and methods of converting to and maintaining that cover developed. For this purpose fenced areas have been established on the Salt River experimental area above Granite Reef Dam to evaluate the effect of grazing on a tamariskbermudagrass association. In order to evaluate the Fleco root plow as a means of removing a heavy stand of tamarisk, experimental sites have been established along the Gila River near Gillespie Dam. Survival and regrowth counts will be made after treatment by the plow.

\section{Status}

Inactive.

Results

Grazing slows down the development of tamarisk seedlings and sprouts. Root plowing in June killed all but about 15 tamarisk shrubs per acre.

\section{Publications}

Utilization of five-stamen tamarisk by cattle, by H. L. Gary: Rocky Mtn. Forest and Range Expt. Sta. Res earch Note 51, 4 p., 1960.

Use of a root plow in clearing tamarisk stands, by J. S. Horton: Rocky Mtn. Forest and Range Expt. Sta. Research Note 50, 6 p., 1960.

$$
\text { Ariz- } 8
$$

Title

Controlled clipping and regrowth study of Tamarix pentandra.

\section{Agency}

U.S. Forest Service, Rocky Mountain Forest and Range Experiment Station.

\section{Leader}

$$
\text { C. J. Campbell. }
$$

\section{Description}

Repeated clipping of tamarisk by removing all photosynthetic tissue at intervals of 2, 4, 8 , and 24 weeks was carried on in the summers of 1962 and 1963. Simulated mowing treatment at the same intervals was begun in 1963.
Status

Fieldwork completed after two growing seasons.

Results

Controlled clipping of Tamarix pentandra in dicates that increased frequency of treatments increased mortality and decreased foliage production. Significantly decreased carbohydrate root reserves resulted from increasing frequency of treatments. Clipping every 2 weeks was more effective in killing tamarisk than the 4-week, 8-week, or biyearly clipping. No mortality resulted from simulated mowing treatments.

Publication

Eventually, research note.

$$
\text { Ariz-9 }
$$

Title

Successional studies of tamarisk and related phreatophytes.

Agency

U.S. Forest Service. Rocky Mountain Forest and Range Experiment Station.

\section{Leaders}

$$
\text { C. J. Campbell and J. S. Horton. }
$$

\section{Description}

Tamarisk has spread widely throughout flood plains and along streams in the Southwestern United States. Observations are being taken to observe changes in tamarisk distribution. Effect of submergence upon Tamarix pentandra is being determined on a reservoir delta. Permanent transects and quadrats at known elevations have been installed and will be read at yearly intervals to determine growth and survival before and after submergence.

Status

Active.

Results

Established stands of tamarisk on the Tonto delta or Roosevelt Lake were inundated in 1960. A few large tamarisk shrubs, 8-16 feet high, survived root and partial crown inundation for a period of 12 months, but most 
plants in the area were killed. Tamarisk and scattered mesquite seedlings now have reinvaded much of the killed area.

Observations in many areas indicate that tamarisk may sometimes be decreasing. For instance, on the Pecos River in southwest Texas, because of lower water tables, fire, and grazing, tamarisk is being killed over large areas. Along the Gila River, west of Safford, Ariz., clearing by farming removed approximately 16 percent of tamarisk during the period 1944-58.

\section{Publication}

No definite plans for publication have been made.

$$
\text { Ariz-10 }
$$

(8, Circ. 413)

Title

Saltcedar control.

\section{Agencies}

U.S. Agricultural Research Service, Crops Research Division, and U.S. Bureau of Reclamation.

\section{Leaders}

H. Frèd Arle, U.S. Agricultural Research Service; C. W. Bowser, U.S. Bureau of Reclamation.

\section{Description}

A joint investigation of the means for the control of phreatophytes, particularly saltcedar, through chemical and mechanical methods is being undertaken. The effectiveness of various herbicides is tested by varying the rate, time, method, and number of applications on replicated plots of saltcedar regrowth of different ages. At the start of the study, all mature saltcedar plants were cut off at the land surface by a bulldozer, and the area was divided into 100 quarter-acre plots, separated by 12 -foot access lanes. Age of the regrowth is from the date of cutting of the mature plants. Application of the herbicides is by ground-operated equipment.

\section{Status}

Tests were completed (May 1964) on an area south of Buckeye, Ariz:, where experimental work was designed to test the effectiveness of several herbicides when applications were repeated as annual spring of fall treatments.
Results

1. Saltcedar is more difficult to kill in flood plains than along irrigation channels and streams.

2. Single-spray operations have frequently given 90-percent kill of saltcedar when Silvex was applied at 5 to 10 pounds per acre, the applications being made during spring months after foliage had become fully reestablished.

3. Periodic spraying of infested areas with 2, 4-D and 2, 4, 5-T will defoliate saltcedar and in this manner reduce transpiration losses.

4. Applications of 2, 4-D and related materials appear more effective on young regrowth following mechanical destruction than on adult saltcedars.

5. Application rates of less than 2 pounds per acre have generally given poor results.

6. Low-volatile esters of 2, 4-D or combination of 2, 4-D and 2, 4, 5-T have been consistently more effective than amine or sodium salts of 2, 4-D.

7. Mechanical means, although expensive, are useful in the eradication of saltcedar, especially in areas near cotton or other crops susceptible to 2, 4-D. Mechanical control must be exercised at least yearly to eliminate regrowth from root sprouts and seedlings.

8. Mechanical clearing followed by spraying of young regrowth with 2, 4, 5-TP (Silvex) at 4 pounds or more per acre repeated annually during spring months appears to be the most effective and practical method now known for controlling saltcedar. First applications have generally resulted in 80-percent plant kill.

\section{Publications}

Results of first 2 years published in "Progress Report on Cooperative Saltcedar Control Investigation" prepared for presentation March 11-13, 1958, to Phreatophyte Subcommittee, Pacific Southwest Inter-Agency Committee. Periodic reports will be issued from time to time.

$$
\text { Ariz-11 }
$$

(9, Circ. 413)

\section{Title}

Use of water by saltcedar grown in evapotranspirometers with a controlled water level and evaluation of the energy budget and mass transfer methods of computing water use. 


\section{Agencies}

U.S. Geological Survey and U.S. Bureau of Reclamation.

Leader

T. E. A. van Hylckama, U.S. Geological Sur vey.

\section{Description}

Six evapotranspirometers of plastic membrane construction, having about 1000 square feet of surface area and being 12 to 14 feet deep, were installed in 1959 and planted to saltcedar. Water level in the tanks is maintained at three different levels in pairs of tanks. The water level is controlled by magnetic valves, and water use is measured by water meters.

Instrumentation for measuring incoming and outgoing radiative and sensible heat, wind movement, vapor pressure, and air and soil temperature at several different levels have been in operation since 1960. The data are recorded automatically on electronic recorders.

Five additional tanks were installed in 1962 to measure water loss from bare soil, and differences in the use of water of different salinities by saltcedar.

Status

Active.

Results

\section{Publications}

Buckeye project-water use by saltcedar, by T. W. Robinson and C. W. Bowser: U.S. Geol. Survey and U. S. Bur. Reclamation, 5963 Phreatophyte Subcommitte mtg., Pacific Southwest Inter-Agency Comm., 26 p., 1959.

Measuring water use by saltcedar, by T. E. A. van Hylckama: Arizona Water Resources Comm. and State Land Dept., Proc. 4th Ann. Arizona Watershed Symposium, p. 22-26, 1960.

Use of water by saltcedar (Tamarix pentandra) as measured by the water-budget method (a preliminary report) [abs.], by T. E. A. van Hylckama: Jour. Geophys. Research, v. 67, p. 3535,1962 [rept. is 23 p.].
Growth, development and water use by saltcedar (Tamarix pentandra) under different conditions of weather and access to water, by T. E. van Hylckama: Internat. Assoc. of Sci. Hydrology, Comm. for Evaporation, Pub. 62, p. 7586, 1963.

$$
\text { Ariz-12 }
$$

Title

Gila River Phreatophyte Project.

Agency

U.S. Geological Survey.

Leader

R. C. Culler.

Description

A water budget for a 15-mile reach of the Gila River flood plain on the San Carlos Indian Reservation is being used to determine the changes in evapotranspiration produced by the removal of existing phreatophytes. The study reach, which has been divided into three subreaches for comparative evaluation, contains 8,300 acres of saltcedar and mesquite. The water budget will include inflow and outflow of surface and ground water, precipitation, and change in storage of ground water and soil moisture. The budget will be evaluated for the period 1963-66 with phreatophytes undisturbed. During the winter of 1966-67, the phreatophytes will be removed, and a beneficial vegetation, probably bermudagrass, will be substituted. The water-budget evaluation for the substitution vegetation will be continued through 1968 . The energy budget for the flood plain will be sampled during the study period and related to evaporation from San Carlos Reservoir. Sediment studies will be made to measure the effect of vegetation alteration on erosion and deposition in the reach. Chemical quality of both surface and ground water will be studied.

Status

Instrumentation for basic coverage is complete.

Results

No results at present.

Publications

Annual open-file reports, progress reports as Water-Supply Papers at 3-year intervals. 
Final report as a Water-Supply Paper by 1969.

$$
\text { Ariz-13 }
$$

Title

Use of water by phreatophytes.

\section{Agencies}

U.S. Geological Survey and U.S. Bureau of Reclamation.

\section{Leader}

G. H. Hughes, U.S. Geological Survey.

\section{Description}

Evapotranspirometers are being used to determine water use by arrowweed, saltbush, cattail, and carrizo and to determine evaporation from the soil surface. The results will provide a basis for estimating consumptive use by native vegetation in the lower Colorado River basin and the potential water salvage which could be attained by eradication of the vegetation. The study began with the construction of the evapotranspirometers in 1961, and data collection will continue through 1964.

\section{Status}

Nine tanks each 1000 square feet in area were successfully operated during 1962 and 1963 near Imperial Camp, Calif., and about 20 miles north of Yuma, Ariz. Three of the tanks were planted to arrowweed, three planted to saltbush, and three left unplanted. Growth of the vegetation was substantial during 1963, but full development will not be attained in all the tanks until the end of the 1964 growing season.

Three tanks (each 100 square feet in area) of cattail were operated successfully at nearby Mittry Lake, Ariz., during 1962 and 1963. The cattail first reached full growth in 1962 and reached heights of between 6 and 7 feet each year. Development of carrizo growth in two similar tanks at Mittry Lake has been only partially successful.

\section{Results}

In 1963 water use from the tanks averaged about 8 acre-feet per acre by cattail, 6 acrefeet per acre by arrowweed, and 4-acre feet per acre by saltbush. Depth to water was 5 feet in saltbush and arrowweed tanks-the cattail grew in standing water.
Annual water use by arrowweed and saltbush should be greater in 1964 due to the greater amount of vegetation in the tanks.

Annual evaporation from bare-soil tanks in 1963 was about 6 inches with depth to water at 3 feet and about 3 inches with depth to water increasing uniformly from 3 to 4 feet during the year (rainfall, 5.21 inches, not included). Data for part of a year indicated that evaporation for depth to water of 2 feet was twice that occurring at 3 feet.

\section{Publications}

Progress reports are issued annually beginning in 1963, and a final report will be published.

$$
\text { Ariz-14 }
$$

Title

A study of the effects of phreatophyte removal on water, soil, and vegetation relations.

\section{Agencies}

University of Arizona, sponsored by the U.S. Bureau of Reclamation. Cooperators: U.S. Forest Service, U.S. Geological Survey, U.S. Bureau of Indian Affairs, and the San Carlos Apache Tribe.

\section{Leaders}

P. B. Rowe, Arnett C. Mace, Jr., and John M. Tromble, University of Arizona.

\section{Description}

The objectives of this project, located in the flood plain of the Gila River on the San Carlos Indian Reservation, are to (1) evaluate effects of phreatophytes (particularly saltcedar and mesquite) on streamflow, evapotranspiration, and water yields, (2) determine effects of phreatophyte removal on water yields, channel erosion, water flows and water quality, and develop methods of predicting these effects, and (3) select and test replacement vegetation (principally grasses) and develop methods of establishing and maintaining an effective and desirable vegetation following phreatophyte removal.

Three 200-foot cross sections have been established to evaluate water use by saltcedar, mesquite, and replacement vegetation. Evapotranspiration will be determined by the "Decker tent", soil moisture by the neutron scattering technique, and ground-water 
changes by wells and recorders. A wellequipped climatic station is in operation and will be used to measure air and soil temperature, precipitation, net radiation, relative humidity, and wind speed and direction. This study should provide a basis for predicting potential amounts of water salvage resulting from eradication and replacement vegetation for given climatic and physiographic conditions.

Status

Active.

Results

None as yet.

Publications

None.

$$
\text { Ariz-15 }
$$

Title

Feasibility of establishing replacement type vegetation in cleared floodways in Arizona.

\section{Agencies}

U.S. Bureau of Reclamation, U.S. Corps of Engineers, and Agricultural Experiment Station, University of Arizona.

\section{Leaders}

Bruce Powers, K. C. Hamilton, and John M, Tromble, University of Arizona.

\section{Description}

The feasibility of revegetating cleared floodway channels as a means of controlling phreatophytes, reducing annual maintenance costs, and reducing erosion was investigated over a 3-year period. The study area consisted of three 150-foot by 100-foot plots in the Snyder floodway near Wellton, Ariz. One of the objectives was to find suitable plants that could be grown following clearing. To this end 15 species of forage grasses were planted and replicated in the three plots. Plantings were by seed or propagated plants. Tolerance of the various species to salty water was tested by wetting one plot with salty water and another with fresh water before planting.

\section{Status}

Study completed in 1963.
Results

No germinations were observed in plants irrigated with water containing 5,170 ppm (parts per million) total salts. Grass species irrigated with fresh water that established the best stands were blue panic, giant bermudagrass, coastal bermudagrass, creeping dropseed, and common bermudagrass. Volunteer establishment of bermudagrasses and blue panic grasses in the cleared floodway indicates that under certain conditions these grasses can be used to revegetate floodways at lower elevations in the Southwest.

\section{Publication}

Revegetation of a cleared section of a floodway, by Bruce Powers and K. C. Hamilton: Univ. of Arizona, Rept. 198, Apr. 1961.

\section{CALifornia}

$$
\text { Calif- } 1
$$

(10, Circ. 413)

Title

Phreatophyte research. Agency

$$
\text { U.S. Geological Survey. }
$$

Leader

$$
\text { T. W. Robinson. }
$$

\section{Description}

A comprehensive and coordinated research program on the phreatophyte problem is needed to estimate the quantity of the ground water consumptively wasted by nonbeneficial phreatophytes and to evaluate the quantity that can be salvaged. The effect of consumptive waste on the quality of the ground water is also under investigation. The fields of study involved in these objectives are: (1) a knowledge of the habitats and characteristics of nonbeneficial phreatophytes, (2) the factors that control their occurrence, (3) the factors that control evapotranspiration of ground water by them, and (4) economic methods for salvaging the consumptive waste. In these hydrologic and ecologic fields of study, information is needed on the occurrence of phreatophytes by species, the relation of their occurrence to the depth and quality of the ground water, areas of growth, their cover density and plant size, depth of root penetration, and annual water use by species for 
different depth to the water table and different climatic conditions.

Status

Active.

Results

A survey of areas of saltcedar growth shows that, as of 1961 , there was about 900,000 acres of saltcedar in the Western States. Texas had the largest area of saltcedar growth, followed by New Mexico, and next by Arizona. In 1920 saltcedar was estimated to cover only about 10,000 acres. By 1961 saltcedar was found to occur in all of the Southwestern States and to be infesting stream and reservoir areas as far north as central Wyoming.

A handbook for surveying phreatophyte vegetation was prepared and published in cooperation with the U.S. Forest Service and the U.S. Bureau of Reclamation.

\section{Publications}

Phreatophytes, by T. W. Robinson: U.S. Geol. Survey, Water-Supply Paper 1423, 1958.

Selected bibliography of evaporation and transpiration, by $T$. W. Robinson and A. I. Johnson: U.S. Geol. Survey, Water-Supply Paper 1539-R, 1961.

Glossary of terms relating to the phreatophyte problem, by T. W. Robinson: Mimeo. rept. for the Subcommittee on Phreatophytes, Pacific Southwest Inter-Agency Comm., 1962.

Guide for surveying phreatophyte vegetation, by J. S. Horton, T. W. Robinson, and $\mathrm{H}$. R. McDonald: U.S. Dept. of Agriculture, Forest Service, Agriculture Handb. 266, 37 p., illus., 1964.

Introduction, spread, and areal extent of saltcedar (Tamarix) in the Western States, by T. W. Robinson: U.S. Geol. Survey Prof. Paper 491-A, 1964. (In press.)

$$
\text { Calif-2 }
$$

\section{Title}

Vegetative water use studies.

\section{Agency}

California State Department of Water Resources.

\section{Leader}

R. E. Merrill, Associate Land and Water Use Analyst, Northern Branch.

\section{Description}

Two evapotranspirometers at the AlturasDorris Ranch, near Alturas Calif., 36 inches in diameter and 30 inches deep, were installed in 1956 to measure evapotranspiration during the growing season from pasture with a high water table. Water is supplied to the tanks by means of a steady, small flow at a rate calculated to exceed evapotranspiration. The water level is maintained 6 inches below the ground surface, and excess water not consumed in the evapotranspirometer spills into a buried sump tank. Continuous records are kept of both the inflow and outflow, and the difference provides a measurement of the rate and quantity of evapotranspiration. Measurements are also being made of various climatic factors by means of a pyrheliometer, evaporation pan, atmometers, and a precipitation gage. It is anticipated that the study shall continue through 1965.

Status

Active and operating satisfactorily. There were numerous mechanical problems during the first few years.

\section{Results}

The ratio of evapotranspiration to evaporation from a U.S. Weather Bureau standard class A pan is approximately 1.0 for the period April 1 to October 31.

\section{Publications}

California Department of Water Resources Bulletin 113, Vegetative Water Use Studies 1954-60, included the results of 1959 and 1960. Results of 1961,1962 , and 1963 are presently being summarized for publication during this fiscal year.

\section{COLORADO}

$$
\text { Colo-1 }
$$

(12, Circ. 413)

Title

Carbohydrate reserve in tamarisk (saltcedar).

\section{Agencies}

U.S. Bureau of Reclamation and U.S. Agricultural Research Service cooperating with the U.S. Forest Service, Rocky Mountain Forest and Range Experiment Station, and the New Mexico State Engineer's Office. 


\section{Leader}

T. R. Bartley, U.S. Bureau of Reclamation.

\section{Description}

A study to determine the annual cycle of carbohydrate reserves in tamarisk stems and roots. The amount of carbohydrate reserve is frequently associated with growth, vigor, and susceptibility to injury. Thus, information concerning the low point in the carbohydrate root reserves may be useful in timing a control program. Studies of tamarisk plants in greenhouses have shown that applications of various formulations of $2,4-D$ and $2,4,5-T$ cause a reduction of carbohydrate food reserves present in the stem, crown, and root.

Two collection sites were selected to learn the effect of different ecologic conditions on the seasonal trend of reserves. One site was on the delta of the Caballo Reservoir on the Rio Grande in New Mexico, the other on the Salt River in Arizona. The samples from New Mexico were collected by personnel of the State Engineer's Office and from Arizona by the Rocky Mountain Forest and Range Experiment Station.

\section{Status}

Completed.

\section{Results}

The data indicate that carbohydrate food reserves of roots and stems of tamarisk have well-defined periods of low carbohydrate content. The annual low carbohydrate content of the Arizona specimens occurred during the latter part of April, and in the New Mexico specimens it occurred in June. This difference in time could be due to differences in altitude, as the New Mexico site was about 3,000 feet higher. In the Arizona specimens the average carbohydrate content in roots was 5 to 6 percent greater than in the stems.

\section{Publications}

Carbohydrate reserves in tamarisk (saltcedar)-Progress report no. 1, July 1957 through July 1958: U.S. Bur. of Reclamation. Commissioner's Office, Denver, Colo., Chem. Eng. Lab. Rept. SI-19, Oct. 17, 1958.

Carbohydrate reserves in tamarisk (saltcedar)-Progress report no. 2, August 1958 through August 1959: Chem. Eng. Lab. Rept. SI-25, Jan. 29, 1960.

Carbohydrate reserves, in tamarisk (saltcedar)-Progress report no. 3, September
1959 through July 1960: Chem. Eng. Lab. Rept. SI-28, Dec. 19, 1960.

Carbohydrate reserves in tamarisk (saltcedar)-Progress report no. 4, August 1960 through July 1961: Chem. Eng. Lab. Rept. W-3, Nov. 30, 1961.

Carbohydrate reserves in tamarisk (saltcedar)-Progress report no. 5, August 1961 through July 1962 (final report): Water Conserv. Rept. W-7, April 15, 1963.

Annual cycle of carbohydrates in saltcedar (Tamarix pentandra Pall.), by T. R. Bartley and N. E. Otto, Bureau of Reclamation, Denver, Colo., paper presented at Western Weed Control Conference at Salt Lake City, Utah, Mar. 21 and $22,1961$.

$$
\text { Colo -2 }
$$

Title

Control and eradication of saltcedar and other phreatophytes.

Agency

U.S. Bureau of Reclamation, Devision of Research.

Leader

P. M. Turner, U.S. Bureau of Reclamation.

\section{Description}

Studies are conducted in greenhouse and nursery to determine effective and economical means of controlling saltcedar and other phreatophytes. Saltcedar and other phreatophytes are propagated and cultured for greenhouse and nursery study purposes. In the study of chemical methods of control, systemic herbicides are foliar applied at different rates and are timed with phenological growth stage. Effects of different herbicidal additives on improving translocation of materials within the plant will be studied. Evaluation of mechan ical and combined mechanical and chemical methods of control will be included in the study. Carbohydrate content of treated and untreated plants is analyzed to determine the relationship of this factor to phreatophyte control.

\section{Status}

These studies have been in progress since 1961, and they will continue.

\section{Results}

Techniques for propagating and culturing suitable plants for greenhouse and nursery 
studies have been developed. Methods are being developed for evaluating effectiveness of control treatments. Greenhouse evaluation techniques reflect gross differences in the potential effectiveness of herbicidetreatments.

\section{Publications}

Annual report of phreatophyte activities, 1961: U.S. Bur, of Reclamation, Office of Assistant Commissioner and Chief Engineer, Denver, Colo., Water Conserv. Rept. W-5, April 27, 1962.

Annual report of phreatophyte activities, 1962: U.S. Bur. of Reclamation, Office of Chief Engineer, Denver, Colo., Water Conserv. Rept. WC-3, June 20, 1963.

\section{Colo-3}

Title

Phreatophyte growth in the Arkansas River valley of Colorado.

\section{Agencies}

Colorado State University, Civil Engineering Section, in cooperation with the Ground Water Branch of the U.S. Geological Survey, funded in part by the Colorado Water Conservation Board.

\section{Leader}

Morton W. Bittinger, Colorado State University.

\section{Description}

The reach of the Arkansas River valley lying between La Junta and Las Animas was chosen for a field study. Aerial photographs taken in 1957 were used to make a general classification of areas on the basis of density and type of vegetation. Field determinations of species and densities were made at 211 sampling points. Aerial photographs taken in 1936,1947 , and 1957 were used to estimate the changes in vegetative growth since 1936 . Results in the La Junta to Las Animas study area were extended to the entire valley from Pueblo to the Colorado State line through use of aerial photographs.

\section{Status}

The phreatophyte portion of the over-all study has been terminated.
Results

Approximately 3,660 acres of phreatophyte trees and shrubs are growing in the Arkansas River valley between La Junta and Las Animas. Over 83 percent of this growth is benefited by a water table at less than 5 feet below the ground surface. Another 2,000 acres of grass and weeds also occupy land in which the water table is less than 5 feet below the land surface. Cottonwoods are the predominant species of trees, whereas saltcedars are the predominant shrub. Willows constitute a small part of the total tree and shrub growth. An increase in acreage of tree and shrub growth occurred between 1936 and 1957, averaging approximately 50 acres per year. An increase of density in growth also occurred during this period. Approximately 15,000 acre-feet of water is now being consumed annually by phreatophytes in this reach of the river. This has increased at least 4,000 acre-feet since 1936 .

\section{Publication}

A study of phreatophyte growth in the lower Arkansas River valley of Colorado, by M. W. Bittinger and G. E. Stringham: Civil Eng. Sec., Colorado Agr. Expt. Sta., CER63 MWBGES6, April 1963.

\section{KANSAS}

Kans-1

(13, Circ. 413)

Title

Ecologic research on saltcedar.

Agencies

Fort Hays Kansas State College, Division of Biological Science, cooperating with U.S. Bureau of Reclamation.

\section{Leaders}

Gerald W. Tomanek and Robert L. Ziegler, Fort Hays Kansas State College.

\section{Description}

An ecologic study of saltcedar at Cedar Bluff Reservoir, Kanopolis Reservoir, Smoky Hill River and tributaries, Kirwin and Webster Reservoirs, and Solomon River in Kansas and in selected areas in Texas and New Mexico. A description of vegetation as a whole, saltcedar infestations, and a description of saltcedar communities as to density, 
age classes, variations in growth, and seedling counts. Studies of life history, reproduction, water usage, and competition are also being considered.

The primary goal of this study is to describe the life history of the plant and its development in Kansas.

\section{Status}

Work has been completed and final report has been mimeographed and distributed by U.S. Bureau of Reclamation. A few copies are still available.

\section{Results}

The viability of saltcedar as such is not a limiting factor in the spread of the plant. Viability was found to range from 19.0 to 51.4 percent, with an average of 32.5 percent. Each mature plant produces nearly half a million seeds annually. The highest germination occurred with solutions that had a pH of between 5.6 and 7.0 and were weakly saline. Seeds stored at low temperatures had a higher rate of germination than those stored at high temperatures.

Transpiration studies of three phreatophytes-saltcedar, cottonwood, and willowshowed that total water loss for plants of the same size was greatest for saltcedar. On the basis of loss per square decimeter of leaf area per day, the loss was least for saltcedar, 3.80 grams, while for cottonwood it was 5.80 grams, and for willow 8.23 grams. The greater total loss for saltcedar was due to the greater leaf area.

Seedling survival and growth was greatest in sodium chloride solutions of 0 to 3,000 ppm. The seedlings withstood concentrations of up to $4,000 \mathrm{ppm}$, but at $5,000 \mathrm{ppm}$ all seedings died.

Other studies made include community relationships, vegetative reproduction, anatomical studies, root development, carbohydrate analysis of roots, effects of clipping, competition and replacement, inundation effects, and distribution.

\section{Publications}

Life history of saltcedar (Tamarix gallica L.): Kansas Acad. Sci. Trans., v. 60, no. 4, 1957.

A study of the woody vegetation at Cedar Bluff Reservoir: Kansas Acad. Sci. Trans., v. 60, no. $4,1957$.
Annual report on ecological research of saltcedar and other vegetation primarily at Cedar Bluff Reservoir, Kansas: Fort Hays Kansas State Coll., Dept. of Biology, Div. of Biol. Sci., 1956, 1957, 1958, 1959. [Mimeo.]

Ecological studies of salt cedar: Fort Hays Kansas State Coll., Div. of Biol. Sci., 1960. [ Lithographed]

\section{Kans-2}

\section{Title}

The effects of saltcedar on the saline subirrigated range along the Cimarron River in Clark County, Kansas.

Agency

Fort Hays Kansas State College, Division of Biological Science (student research project).

\section{Leader}

Sam E. Stranathan, student, Fort Hays Kansas State College.

\section{Description}

Evaluation of the effects of saltcedar upon the herbaceous vegetation normally comprising the total composition of the very productive subirrigated range site. Comparison of composition and production of native vegetation as affected by open and dense stands of saltcedar. Comparisons were also made between treated and untreated dense stands.

\section{Status}

Special research problem in botany worked out by a student. Completed in 1963.

Results

Dense stands of saltcedar greatly retard growth of herbaceous vegetation on a productive range site along the Cimarron River. Basal cover of vegetation was reduced 50 percent by competition, and many desirable forage grasses have completely disappeared. Production of herbaceous vegetation in a dense stand of saltcedar was only 24 percent of that on an area without saltcedar. A treated dense stand compared favorably with an uninfested area. The open stand of saltcedar did not greatly affect the herbaceous vegetation except that it influenced the distribution of grazing animals. Certain native herbaceous plants were more tolerant of 
saltcedar than others and are indicated below:

\section{Limited Tolerance}

Alkali sacaton

Vine mesquite

Western wheatgrass

Inland saltgrass

Bermudagrass
Intolerant

Prairie cordgrass Switchgrass

Sand lovegrass

American licorice

Yellow sweetclover
Considerable infestation of saltcedar stands in this area by the shothole borer (Amphicerus hematus) was noted. This might be a good organism to investigate as a possible biological control.

\section{Publication}

The effects of saltcedar on saline subirrigated range along the Cimarron River in Clark County, Kansas, by Sam E. Stranathan: Fort Hays Kansas State Coll., Div. of Biol. Sci., 1963. [Mimeo.]

\section{NEVADA}

Nev- 1

(14, Circ. 413)

Title

The effect of water-table depth on irrigation requirements and yield of Lahontan alfalfa.

\section{Agency}

U.S. Agricultural Research Service, Soil and Water Conservation Research Division.

Leader

Rhys Tovey, U.S. Agricultural Research Service.

\section{Description}

To determine surface-irrigation requirements of Lahontan alfalfa grown on three soil textures with constant water tables at various depths and on well-drained soil in the absence of a water table; to determine the effect of plant-growth stage on the rate of water use by Lahontan alfalfa; to determine the relation between the use of water by alfalfa under various water-table conditions, evaporation from porous atmometer bulbs, and evaporation from a Weather Bureau evaporation pan; and to evaluate the effects of a fluctuating water table on the yield and growth rate of alfalfa.
Status

Completed.

Results

\section{Static water tables}

1. A three-season average of consumptive use and yield of alfalfa, disregarding soil textures, shows an almost straight-line relationship with water-table depth for the nonirrigated treatment.

2. The nonirrigated alfalfa definitely shows the effects of static water-table depth on the consumptive use and yield of alfalfa, as no error is introduced by surface-water application.

3. Peak consumptive use occurred when the alfalfa was at or approaching the onetenth bloom stage and temperatures were high.

4. Only minor differences in the growth of alfalfa were found for the various watertable, soil, and irrigated treatments.

5. The alfalfa plants in the lysimeters showed good root development, with roots in the capillary zone and enlarged white rootlets extending below the water-table level.

\section{Fluctuating water tables}

Significant results of the fluctuating watertable study are:

1. Excess water must be removed from the root zone of alfalfa plants adapted to 2foot static water tables within 3 days to insure optimum crop production.

2. Alfalfa root system deterioration became progressively worse as the fluctuation or submergence intervals exceeded 4 days.

\section{Publications}

Consumptive use and yield of alfalfa grown in the presence of static water tables, by Rhys Tovey: Univ. of Nevada Agr. Expt. Sta. Tech. Bull. 232, June 1963.

Water table fluctuation-effects on alfalfa production, by Rhys Tovey. Will be published as University of Nevada Agricultural Experiment Station Technical Bulletin 1 in the near future. 
Alfalfa growth as influenced by static and fluctuating water tables, by Rhys Tovey. Paper presented at 1963 ASAE winter meeting in Chicago, Ill., and accepted for publication by ASAE Steering Committee.

$$
\text { (15, Circ. 413) }
$$

Title

Utilization of available water supplies in the Colorado River basin of Nevada.

\section{Agencies}

U.S. Agricultural Research Service, Soil and Water Conservation Research Division, cooperating with University of Nevada, Nevada Agricultural Experiment Station; U.S. Soil Conservation Service; Nevada Department of Conservation and Natural Resources; and U.S. Weather Bureau.

\section{Leader}

V. I. Myers, U.S. Agricultural Research Service.

\section{Description}

Saltgrass was grown in tanks, with a 2-foot water table, at 3 locations: Logandale, Caliente, and Mesquite. Records of weather and evapotranspiration have been gathered for 2 years. Correlations and regression equations that relate evapotranspiration to weather records have been computed.

\section{Status}

\section{Discontinued.}

Results

At one location the saltgrass yield was nearly 10 times greater and the evapotranspiration nearly 4 times greater than that occurring at another location having almost identical climatic conditions during the growing season. This fact demonstrates the importance of relating the consumptive use of phreatophytes to stand densities or yields.

\section{Publication}

None.

$$
\begin{gathered}
\text { Nev-3 } \\
\text { (16, Circ. 413) }
\end{gathered}
$$

Title

Increased streamflow and forage production through eradication of undesirable vegetation, reseeding, and grazing management.

\section{Agencies}

University of Nevada, Nevada Agricultural Experiment Station, U.S. Agricultural Research Service, Soil and Water Conservation Research Division.

\section{Leader}

\section{J. H. Robertson, University of Nevada.}

\section{Description}

Numerous ranches in Nevada rely on small creeks for their irrigation water. The success of the operation quite often is limited by the streamflow after snowmelt. Usually there is a dense growth of shrubs and trees along the streams. Transpiration by this vegetation causes large diurnal fluctuations in the streamflow, especially during the latter part of the irrigation season. Clearing this vegetation should increase the streamflow and reduce the amplitude of the diurnal fluctuation. To this end, the feasibility of using herbicides and controlled burning to eradicate the vegetation were being studied. Reseeding of the cleared areas with grasses should increase forage production and also prevent gullying in the cleared areas.

Changes in streamflow were measured by Parshall flumes, equipped with 8-day waterlevel recorder. Changes in ground-water levels also were measured by water-level recorders. With the start of the project on July 1, 1958, streamflow measurements were made on two streams. However, during the dry years of 1959, 1960, and 1961, the streams ceased to flow. Even after the wet years of 1962 and 1963, the streams flowed only briefly and erratically; nor did normal flow resume in 1964 .

Since 1962 fairly continuous records have been obtained with water-level recorders on two sets of paired wells-one well in sagebrush growth, the other in seeded grass cover.

\section{Status}

The study is continuing, but owing to the lack of streamflow it was modified to study use of ground water by the vegetation.

\section{Results}

During the periods of flow in the streams, the peaks occurred in early morning and the minimum flow about 12 hours later. Daily loss in early September 1958 was estimated as 1,370 gallons in 1 mile of a small tributary stream. 
Indications are that grass, in a good stand in the canyon bottom, will use as much water during the season as does the big brush. The grass begins to use water more rapidly earlier in the spring than does the brush, whereas the brush continues to use it a little later in the summer. An attempt is being made to quantify water usage.

\section{Publications}

The flow of small springs and creeks during a drought year, in Range management research progress report, 1959-60: Circ. 25, p. 20-21, Dec. 1959.

Water requirement of big sagebrush, in Range management research progress report, 1960-61: Circ. 33, p. 15, Mar. 1961.

Water table and vegetation in a canyon bottom, in Progress report-Research in range management and entomology, 1961-62: Circ. 36, p. 23.

Estimated evapotranspiration as reflected by fluctuations in water tables under big sagebrush and grass, in Progress reportResearch in range management and entomology, 1962-63: Circ. 41, p. 26-28.

Transpiration by big sagebrush under controlled temperature, in Progress reportResearch in range management and entomology, 1962-63: Circ. 41, p. 29-30.

These are all published by the Max C. Fleischmann College of Agriculture, University of Nevada, Division of Plant Science.

$$
\text { Nev }-4
$$

\section{Title}

Evapotranspiration studies on native meadowgrasses in Humboldt River basin, Nevada.

\section{Agencies}

U.S. Agricultural Research Service, Soil and Water Conservation Research Division.

\section{Leaders}

A. S. Dylla and Dean C. Muckel, Agricultural Research Service.

\section{Description}

To determine the evapotranspiration of native meadowgrasses growing in areas of shallow water tables of the Humboldt River basin. Grasses-predominantly sedges, bluestem, and saltgrass-are grown in polyvinyl plastic-lined tanks called evapotranspirometers that are 10 feet square and 7 feet deep. These evapotranspirometers have a controlled water supply which permits the accurate measurement of all water consumed by the plants.

The records of water use are checked against water use at seven locations on meadowlands as determined by daily watertable fluctuations and soil moisture changes above the water table. The soil moisture changes are measured with a neutron scattering meter. Climatic data, including temperature, humidity, wind, and evaporation rate are obtained at each location, and attempts are being made to correlate water use with these data.

Status

Active.

Results

There are now 3 years of data available on use of water by native grasses, as measured in evapotranspirometers. Owing to establishment of grasses in the spring of 1961, records of water use for this year represent only a partial season. In 1962, records were obtained on use of water by grasses growing under constant shallow (4 feet) water-table conditions. In 1963, water-table depths in the evapotranspirometers were regulated to simulate the ground-water levels recorded in the adjacent meadows; that is, the water level was fluctuated between 1 and 2 feet from the ground surface through May and June and then allowed to decline below the 4 foot depth for the remainder of the season. Soil-moisture contents of the soil profile above the water table were measured with a neutronscattering meter.

Grasses subjected to a simulated wet meadow (fluctuated high water-table) condition, as in 1963, produced less hay per unit of water used than when grown under a constant shallow (4 feet) water table, as in 1962.

\section{Publications}

Plastic membrane tanks for evapotranspiration determinations, by A. S. Dylla and Rhys Tovey: Agr. Eng., v. 43, (10), p. 584, 585, Oct. 1962 . 
Phreatophytes-How much water do they waste?, by Dean C. Muckel and A. S. Dylla: Nevada Ranch and Home Review, p. 12, 13, fall and winter, 1964.

\section{Nev- 5}

Title

Establishment of replacement vegetation of higher economic value in phreatophyte areas of the Great Basin.

\section{Agencies}

U.S. Agricultural Research Service, Soil and Water Conservation Research Division, and Crops Research Division.

\section{Leaders}

A. S. Dylla and R. E. Eckert, U.S. Agricultural Research Service and Crops Research Division.

\section{Description}

An experimental field study, the purpose of which is to develop techniques for providing supplementary moisture to aid establishment of replacement species in the phreatophyte (primarily greasewood and rabbitbrush) areas; to evaluate methods of seedbed preparation: to evaluate species for stand establishment; and to determine sustained forage yields from established stands upon discontinuance of applying supplementary irrigations.

\section{Status}

Active project initiated in 1961.

Results

Tall wheatgrass (Agropyron elongatum) and Great Basin wildrye (Elymus cinereous) presently appear to be the two forage species adaptable to the saline-alkali soils of the greasewood-rabbitbrush sites. Sprinkler irrigation appears to be the most suitable method for applying supplemental moisture to the soil site without land farming or grading.

\section{Publication}

Plans for publishing experimental results following the 1964 season.

\section{Nev-6}

Title

Evapotranspiration studies of phreatophytes in the Humboldt River valley, Nevada.
Agencies

U.S. Geological Survey, Nevada Department of Conservation and Natural Resources, and U.S. Bureau of Reclamation.

\section{Leader}

T. W. Robinson, U.S. Geological Survey.

\section{Description}

The Humboldt River research project, begun in mid-1959 under a State-Federal cooperative program, sought information for evaluating the land and water resources of the Humboldt River basin and for developing programs for their effective utilization. One facet of the study was to determine the amount of water used by nonbeneficial phreatophytes.

For this purpose 12 evapotranspiration tanks, or evapotranspirometers, were constructed at a test site on and adjacent to the Humboldt River flood plain near Winnemucca, $\mathrm{Nev}$. The tanks ranged in size from 10 feet square and 7 feet deep to 30 feet square and 10.5 feet deep. Seedlings of four species of phreatophyte were transplanted in the tanks as follows: Greasewood in two tanks; rabbitbrush, willow, and wildrose each in three tanks: and nothing in one tank. After establishment of plant growth, water levels were maintained at 5 feet below the surface of the tanks, with the exception of the bare soil tank. Use by the plants is equal to the water, including rainfall, added to the tanks during the growing season, plus or minus differences in soil moisture at the beginning and end of the season.

During the 1962 growing season there was partial defoliation of the plants in the greasewood tanks as the result of toxic concentrations of salts, largely of boron, in the root zone. In order to correct this condition, and to prevent similar damage to the rabbitbrush plants in adjacent tanks, the greasewood and rabbitbrush tanks were leached by backwashing following the 1962 .growing season.

In order to express water use in units of foliage volume, as well as in units of area, measurements of plant foliage in the tanks are made at the height of the growing season. Photographic records of the plant are made at periodic intervals during each growing season.

\section{Status}

The study is planned to continue for another 3 years while maintaining the water 
levels at different depths, beginning with a 6 -foot depth to water in the greasewood tanks in 1964.

\section{Results}

The use of water during the 1963 growing season by the various species, on a depth and a volume of foliage basis, is given in the tabulation that follows.

\begin{tabular}{|c|c|c|}
\hline Species & $\begin{array}{l}\text { Depth } \\
\text { (feet) }\end{array}$ & $\begin{array}{l}\text { Volume of foliage } \\
\text { (cubic feet of } \\
\text { water per cubic } \\
\text { foot of foliage) }\end{array}$ \\
\hline $\begin{array}{l}\text { Greasewood } \\
\text { Rabbitbrush } 1 \\
\text { Willow } \\
\text { Wildrose }\end{array}$ & $\begin{array}{l}1.79 \\
2.22 \\
4.0 \\
21.6\end{array}$ & $\begin{array}{r}1.72 \\
2.75 \\
2.95 \\
21.1\end{array}$ \\
\hline
\end{tabular}

Note. - Loss of water from the bare soil tank, with the water level at 2.5 feet, was 0.75 feet.

\section{Publications}

Evapotranspiration tank installation for measuring the use of water by greasewood, by T. W. Robinson, in Progress report, Humboldt River research project: Nevada State Dept. Conserv. p. 14-18, 1960.

Research studies on the use of water by phreatophytes, by T. W. Robinson, in 2d Progress report, Humboldt River research project: Nevada State Dept. Conserv., p. 21-25, 1961.

Research studies on the use of water by phreatophytes, by T. W. Robinson, in 3d Progress report, Humboldt River research project: Nevada State Dept. Conserv., p. 17-23, 1962.

Research studies on the use of water by phreatophytes, by T. W. Robinson, in 5th Progress report, Humboldt River research project: Nevada State Dept. Conserv., p. 13-17, 1964.

\section{NEW MEXICO \\ N. Mex-1 \\ (17, Circ. 413)}

Title

Water-conservation measures and control of vegetation in Caballo Reservoir area, New Mexico.

\section{Agencies}

New Mexico State Engineer's Office and U. S. Bureau of Reclamation.
Leader

James W. Kirby, U.S. Bureau of Reclamation.

\section{Description}

Much of the reservoir area of Caballo Reservoir, a storage facility below Elephant Butte Dam, was covered with a moderate to dense growth of phreatophytes-largley saltcedar. Other phreatophytes were mesquite, cottonwood, willow, and baccharis. A high water table in the reservoir areas above seasonal storage levels offers a favorable environment for phreatophytes. Saltcedar, an aggressive and naturalizing plant, had spread throughout the reservoir area to the extent that it had covered over 6,000 acres. It can readily be seen that there would be a large attendant nonbeneficial consumptive use of water from this large infestation of phreatophytes. A program of conservation was undertaken in 1957 with the following objectives: (1) Conservation of water through the removal of saltcedar and other phreatophytic growth and control of regrowth, and (2) to evaluate the possibility of lowering the water table by rechanneling the Rio Grande through the reservoir delta area.

\section{Status}

Approximately 6,100 acres of phreatophytes has been cleared from the reservoir area by mechanical and chemical means. Only isolated and inaccessible small areas of the original infestation remain, and phreatophytes in these areas will be eradicated shortly. To prevent regrowth of saltcedars from old root systems and to prevent new seedling growth, control measures have been provided on the cleared areas. Chemical spraying continues to be employed on test plots in the inaccessible areas where mechanical methods cannot be used and in other general areas.

\section{Results}

The initial phreatophyte infestation has been cleared by mechanical and chemical means. The problem now is the control of regrowth and restoration of the reservoir areas into native grasses. Several mechanical methods have been employed for regrowth control. Probably the most effective method has been to sever the roots of the saltcedar about 10 inches below ground surface with a root plow pulled by a crawler tractor. After two passes with the root plow an area may be retired from further control measures for an extended time. Rotary cutters and disking are two other 
mechanical methods employed for regrowth control. It is interesting to note that native grasses establish themselves rapidly after an area has been effectively cleared.

Publication

None.

$$
\begin{gathered}
\text { N. Mex }-2 \\
\text { (18, Circ. 413) }
\end{gathered}
$$

Title

Water salvage in the middle Rio Grande Project.

(This is not a research project but is an operating multipurpose project. It is reported because it has resulted in the development of new techniques and in the salvage of water.)

\section{Agencies}

U.S. Bureau of Reclamation and New Mexico State Engineer Office.

\section{Leader}

E. W. Elliott, Project Superintendent, Bureau of Reclamation.

\section{Description}

The water table in the middle Rio Grande valley above Elephant Butte Reservoir from Cochiti on the north to the narrows of Elephant Butte Reservoir on the south is such that it supports a dense growth of phreatophytessaltcedar, willows, and some cottonwoods. These plants consumptively waste many thousands of acre-feet of ground water that could otherwise be used for irrigation, and they also impede flood flows. The objective of the program is to increase available flow in the river by (1) eliminating or controlling water-consuming vegetation, (2) increasing the efficiency of existing drains by enlarging them and clearing them of vegetation, (3) constructing new drains, and (4) channeling side inflow directly to the river, thus lowering the water table.

Status

Active in 1964, with continuing eradication of phreatophyte growth and control of vegetation regrowth.

\section{Results}

Water table lowered and riverflows controlled, which resulted in water being salvaged from water-loving vegetation. Amount salvaged over the past 10 years is estimated at 622,000 acre-feet.

\section{Publication}

Reports of maintenance activities are in cluded in the annual "Report of Phreatophyte Activities," Division of Research, Office of Chief Engineer, Bureau of Reclamation.

$$
\begin{gathered}
\text { N. Mex-3 } \\
\text { (19, Circ. } 413)
\end{gathered}
$$

Title

Appraisal of potential ground-water salvage along the Pecos River between Acme and Artesia.

\section{Agencies}

U.S. Geological Survey. and New Mexico State Engineer's Office.

\section{Leader}

R. W. Mower, U.S. Geological Survey.

\section{Description}

Phreatophytes-such as saltcedar, grasses (saltgrass and sacaton), and mesquite-grow in the bottom land of the Acme-Artesia reach of the Pecos River and consume tens of thousands of acre-feet of water each year. The increase in area and in growth density of saltcedar is continuing uncontrolled, and the water wasted by them increases yearly. The area covered by all phreatophytes in this reach amounted to 41,000 acres in both 1956 and 1958. Saltcedar, which was growing on 23,200 acres in 1956, had increased by 4,900 acres to 28,100 acres in 1958. Coincident with the increase in area was an increase in growth density: the dense growth by 600 acres, the moderately dense by 800 acres, the moderate by 1,000 acres, the sparse to moderate by 800 acres, and the sparse by 1,700 acres. The increase in the area of saltcedar was at the expense of the grasses, which decreased from 14,700 acres in 1956 to 9,800 acres in 1958. Areas and densities were obtained through interpretation of aerial photographs.

\section{Status}

\section{Completed.}

Results

The use of water by phreatophytes in the reach was computed by four methods for the years 1956 and 1958, respectively. The use ranged from 54,000 acre-feet to 88,000 acrefeet (averaging 66,500 acre-feet) in 1956, and from 55,000 acre-feet to 107,000 acre-feet 
(averaging 81,000 acre-feet) in 1958. It is interesting to note that the increase in saltcedar growth in the period was 21.1 percent, while the average increase in use of water was 21.8 percent.

If the saltcedar growth continues uncontrolled, the rate of evapotranspiration might rise to 170,000 acre-feet annually in a few years.

Publication

An appraisal of potential ground-water salvage along the Pecos River between Acme and Artesia, New Mexico, by R. W. Mower, J. W. Hood, R. L. Cushman of the U.S. Geological Survey and R. L. Borton and S. E. Galloway of the New Mexico State Engineer's Office: U.S. Geol. Survey Water-Supply Paper 1659, 1964.

$$
\begin{gathered}
\text { N. Mex }-4 \\
\text { (20, Circ. 413) }
\end{gathered}
$$

Title

Use of water by phreatophytes in the McMillan Delta, Eddy County.

\section{Agencies}

U.S. Geological Survey and Pecos River Commission.

\section{Leader}

J. S. Havens, U.S. Geological Survey.

\section{Description}

The bottom lands of the Pecos River between the Artesia gaging station and Lake McMillan contain about 25,000 acres of saltcedar and other phreatophytic plants. Between the Artesia gaging station and the Rio Penascothe water table is at or near the land surface and is above the level of the Pecos River. Between the Rio Penasco and Lake McMillan the water table is below the level of the river, which flows through a constructed low-flow channel. During periods of low flow in the river and low stage of Lake McMillan, water levels decline and the consumptive use of the saltcedar is small between the Rio Penasco and Lake McMillan. However, periodic flooding of the the Pecos River and the Rio Penasco and high stages of Lake McMillan recharge the water table in the lowlands south of the Rio Penasco, and the consumptive use by the saltcedars is large.

Studies were begun in 1956 to determine the amount of consumptive waste and the re- lation between the ground water in the postMcMillan deposits, the valley fill, and the Permian rocks in the area.

Status

Inactive. Tabulation of data may be resumed in 1964.

Results

No results to report as yet.

Publication

Final report to be published by U.S. Geological Survey.

$$
\text { N. } M e x-5
$$

Title

Rio Grande basin water -salvage investiga tions, New Mexico Division.

(This is not a research project but is a planning study which will develop a plan for optimum salvage of water in the Rio Grande basin above Caballo Reservoir. Some phases could be classed as applied research.)

\section{Agencies}

U.S. Bureau of Reclamation and New Mexico State Engineer Office.

\section{Leader}

Ralph Charles, Area Engineer, Bureau of Reclamation.

\section{Description}

All plans proposed in New Mexico for phreatophyte removal, containing evaluations of nonbeneficial waste, have been criticized for being entirely theoretical and having no actual proof of reality. To overcome such criticism, this study provides (1) the selection of a prototype area containing representative types of phreatophytes, (2) instrumentation of the prototype area and measurement of the water use for three growing seasons, (3) clearing the area of vegetation, and (4) continuing measurements of water use in the prototype area for at least 2 years while the area is maintained free of vegetation. The measured results would be extended over the middle Rio Grande and Espanola valleys in the development of the most feasible plan for phreatophyte control. Three methods of measurement were adopted: (1) The inflow-outflow method, (2) the transpiration well method, and (3) the evapotranspirometer method. Transpiration and observation wells were installed in the prototype 
area as well as at selected locations throughout the area over which the data will be extended. Soil-moisture tubes, in which readings are obtained with a neutron moisture meter, are installed at all transpiration wells.

The evapotranspirometer installation consists of nine large tanks, 1,000 square feet in surface area, and four small tanks. All are automatically controlled. A complete weather station is installed at the site. The location is near Bernardo, New Mex.

Status

Records of 3 years of operation were available at the end of the 1963 growing season, and clearing was underway during the winter of 1963-64.

Results

Pre-clearing conditions established in the prototype area.

\section{Publication}

The results will be published as a plan for water salvage in the Rio Grande basin, New Mexico, above Caballo Reservoir. It is scheduled for completion in 1968.

$$
\text { N. Mex-6 }
$$

Title

Granular and soil-spray applied chemicals for control of saltcedar.

\section{Agencies}

Agricultural Research Service, Crops Research Division, in cooperation with New Mexico State University.

Leader

Eugene E. Hughes, U.S. Agricultural Research Service.

\section{Description}

Studies initiated in 1961 were designed to evaluate granular and soil-spray applied herbicides on saltcedar which could be used in areas where foliage spray applications might be injurious to nearby susceptible crops and where stands are too large for individual tree treatments. Rates of 5 and 20 pounds, on an active ingredient basis, of all granular and soil-spray applied herbicides available from chemical companies were used. Treatments were applied to uniform stands of mature saltcedar with 10-foot buf- fer zones established between plots. All treatments were replicated three times on plots 16.5 by 16.5 feet.

Status

This phase of control research will beterminated in 1964.

Results

To date, nine granular and five soil-spray applied herbicides have been used. Of the nine granular herbicides, only dicamba, 2methoxy-3,6-dichlorobenzoic acid, produced promising results. Another granular herbicide, 2, 3, 6-TBA, killed a low percentage of plants at the highest rate. Dicamba is very promising, even at the lowest (5 $1 \mathrm{~b}$ active ingredients per acre) rate.

Of the soil-spray applied herbicides, none of the five tested killed saltcedar. Fenac defoliated the plants readily, but the effect was not permanent.

\section{Publication}

Results will be published late in 1964 or in 1965 .

$$
\text { N. Mex-7 }
$$

Title

Basal spray for control of saltcedar.

\section{Agencies}

Agricultural Research Service, Crops Research Division, in cooperation with New Mexico State University.

\section{Leader}

Eugene E. Hughes, U.S. Agricultural Research Service.

\section{Description}

Because of drift of spray or fumes from herbicides applied to saltcedar growing on irrigation ditchbanks (in some places adjacent to cotton and other susceptible crops) and the danger of contaminating the water with granular herbicides, dormant basal-spray individual tree treatments seemed to be a possible alternative safe and effective method of control. The technique involves spraying around the base of the tree from the ground surface up 1 to 2 feet. Normally, the herbicides are oil soluble and applied in diesel oil. This project was initiated in the fall of 1961. 
Status

This phase of controlresearch will be terminated in 1964.

Results

Eighteen different herbicides and (or) formulations were applied as basal sprays to saltcedar. Of this group, two formulations of Silvex were superior to all other herbicides: the butoxy ethanol ester and an oil-soluble amine. Additional studies to determine the factors affecting basal-spray applications were carried out. From these studies, it was determined that $12 \mathrm{lb}$ aehg (pounds acid equi valent per 100 gallons of diluent) of Silvex was more effective than $6 \mathrm{lb}$ aehg. It made no difference whether the lower 1 or 2 feet of the base of the plants were sprayed. The cut-stump treatments were superior to both, and the ester formulation was better than the oil-soluble amine. It made no difference whether plants were sprayed in December or in April.

In other studies, it was determined that 8 lb aehg was very effective, so the recommendation probably will be $8 \mathrm{lb}$ aehg of an ester of Silvex in diesel oil, applied any time in late winter to the lower 18 inches of the plants.

\section{Publication}

Results will be published in 1964 .

$$
\text { N. Mex-8 }
$$

Title

Single treatments and combinations of mowing, burning, and spraying for control of saltcedar.

\section{Agencies}

U.S. Agricultural Research Service, Crops Research Division, U.S. Bureau of Sport Fisheries.

\section{Leader}

Eugene E. Hughes, U.S. Agricultural Research Service.

\section{Description}

In order to prevent flooding in the major rivers of the West, agencies not only must kill saltcedar but must remove the dead trees. This project, initiated in 1962, was designed to study various ways of mowing, burning, spraying, and chemical mowing to get maximum kill and remove above-ground parts.

Status

Certain phases of the study will be terminated in 1964, but the more promising ones will be continued.

\section{Results}

Mowing or burning saltcedar stands in the winter and then spraying them with $4 \mathrm{lb}$ ae/A (pounds acid equivalent per acre) of an ester of Silvex in the spring increased the kill about threefold as compared with plants sprayed only. Mowing every 2 months during the growing season, for 2 years, failed to reduce the stand. Burning in the winter followed by mowing in June and then spraying in $\mathrm{Au}$ gust with $4 \mathrm{lb}$ ae/A of the Silvex ester reduced the stand only about 8 percent.

Although plant-kill figures are not available at this time, spraying undisturbed stands in June with $2 \mathrm{lb}$ ae/A of a 2, 4-D amine followed by another application of the same in August appeared to be promising. Another method that appeared promising was spraying an undisturbed stand with $5 \mathrm{lb}$ ae/ $\mathrm{A}$ of a Silvex ester and then mowing 2 to 4 days afterward.

\section{Publication}

Certain phases of this study will be published in 1964.

$$
\text { N. } \operatorname{Mex}-9
$$

Title

Aerial-and ground-applied herbicides for control of saltcedar.

\section{Agencies}

U.S. Agricultural Research Service, Crops Research Division, in cooperation with the U.S. Bureau of Reclamation, Red Bluff Water District, U.S. Soil Conservation Service, and A. P. Atkins, a rancher near Hardesty, Okla.

\section{Leader}

Eugene E. Hughes, U.S. Agricultural Reserach Service.

\section{Description}

Herbicides are applied to plots with a helicopter or fixed-wing aircraft at volumes of 10 and 5 gallons per acre, respectively. 
Ground-applied plots are treated at 20 gallons per acre. Various carriers and formulations of herbicides have been used. Aerialapplied foliage-spray treatments have been made in five States at the time of this writing.

Status

Project will continue as long as necessary to develop a reliable method of control.

Results

Results have been erratic with complete failures common. One series of helicopterapplied foliage-spray treatments in Arizona made in 1962 showed that an ester of Silvex at $4 \mathrm{lb} \mathrm{ae} / \mathrm{A}$ (pounds acid equivalent per acre) and of 2,4-D plus 2, 4, 5-T (50:50) at $4 \mathrm{lb}$ ae/ A were very effective. A similar series made in Texas and New Mexico the same year gave poor results. Results of $1963 \mathrm{aer}-$ ial treatments made in Oklahoma, Texas, Arizona, and Kansas are not known at this time. All treatments appeared to give poor results, however.

Ground-applied foliage-spray studies in New Mexico in 1962, using twelve different herbicides and (or) formulations, showed that the ester and the emulsifiable acid of Silvex were the most promising of those tested. Results of the 1963 ground-applied foliagespray treatments are not known at this time, but there appeared to be no new developments.

Publication

Preliminary results will be published in 1964.

$$
\text { N. Mex- } 10
$$

Title

Factors affecting growth, carbohydrate storage, and susceptibility to herbicides, of saltcedar.

Agencies

U.S. Agricultural Research Service, Crops Research Division, in cooperation with the U.S. Bureau of Reclamation, Red Bluff Water District, U.S. Soil Conservation Service.

Leader

Eugene E. Hughes, Agricultural Research Service.

\section{Description}

In order to develop a reliable chemical control for a perennial plant, it is necessary to determine the factors affecting growth and response to herbicide applications. This project involves measuring the same shoots (fronds) of saltcedar each week, taking root samples for carbohydrate analysis, and collecting data on: evaporation from a freewater surface, wind movement, humidity, air temperature, solar radiation, soil temperature (6 inches), barometric pressure, moisture content of leaves, and salt content of ground water (analysis for calcium, sodium, magnesium, chloride, sulfate, conductivity).

Using a statistical technique, multiple regression analysis, the various factors are evaluated and related to growth, carbohydrate storage, and response to Silvex. It is hoped that an equation can be developed which can be used to estimate carbohydrate storage levels and weekly growth, using one or more of the factors being measured.

\section{Status}

The project is active and will continue at least 1 more year.

Results

After 2 years of work it appears that no one factor or combination of factors presently being measured is sufficiently related to carbohydrate storage and (or) to response to Silvex to develop an estimating equation. One possible explanation is the variability in results of analysis of carbohydrates within each sampling date. Four samples are being taken each week, although possibly 10 or more would give a better picture.

Numerous factors were closely related to shoot length, sodium content of the ground water being the closest single factor ( $r=$ -0.94).

Estimation of weekly growth was possible using minimum air temperature and depth to water table. These factors will be used in 1964 to test their reliability.

Results of a biweekly spray study in 1962 using two rates of Silvex ester (2 and 4 pounds acid equivalent per acre) were inconclusive. The earliest spray date, May 23, was the best, but it gave poor results. 
Publication

Preliminary results will be published in 1964.

$$
\text { N. Mex- } 11
$$

\section{Title}

Effects of water stress on the growth of saltcedar and its response to herbicides.

\section{Agencies}

U.S. Agricultural Research Service, Crops Research Division, in cooperation with the New Mexico Agricultural Experiment Station, Middle Rio Grande Branch Station, Los Lunas, New Mexico, and the U.S. Bureau of Reclamation, Middle Rio Grande Project, Albuquerque, N. Mex.

\section{Leader}

Robt. E. Wilkinson, U.S. Agricultural Research Service, Crops Research Division.

\section{Description}

Measurement of growth and response to herbicides of greenhouse and field-grown saltcedar as affected by water stress.

Status

Initiated May 1, 1964.

Results

None as of July 1, 1964.

Publication

None as of July 1, 1964.

$$
\text { N. Mex-12 }
$$

Title

Anatomy of saltcedar.

\section{Agencies}

U.S. Agricultural Research Service, Crops Research Division, in cooperation with the New Mexico Agricultural Experiment Station, Middle Rio Grande Branch Station, Los Lunas, N. Mex

\section{Leader}

Robt. E. Wilkinson, U.S. Agricultural Research Service, Crops Research Division.
Description

Anatomical and histological studies on the "crown" zone and the frond cuticle of saltcedar.

Status

Studies begun in 1963 and will be continued several years.

Results

Publication

Eventually. Technical journal.

$$
\text { N. Mex-13 }
$$

Title

Evaluation of methods for the propagation of saltcedar by cuttings.

\section{Agencies}

U.S. Agricultural Research Service, Crops Research Division, in cooperation with the New Mexico Agricultural Experiment Station, Middle Rio Grande Branch Station, Los Lunas, N. Mex.

\section{Leader}

Robt. E. Wilkinson, U.S. Agricultural Research Service, Crops Research Division.

\section{Description}

Measurement of effects of seasonal conditions and root promoting compounds on the vegetative reproduction of saltcedar for use in developing an efficient program of producing an adequate continuous supply of uniform vigorous greenhouse-grown plants for chemical evaluation and physiological studies.

\section{Status}

Experiment initiated in 1962 and scheduled for completion in 1964.

Results

Seasonal variations in percentage rooting and shooting of cuttings occur. Response to a root-promoting compound was negative. 
Publication

Technical publication at completion of the study.

$$
\text { N. Mex- } 14
$$

Title

An evaluation of the effectiveness of selected chemical as phreatophyte herbicides or herbicide additives.

\section{Agencies}

U.S. Agricultural Research Service, Crops Research Division, in cooperation with the New Mexico Agricultural Experiment Station, Middle Rio Grande Branch Station, Los Lunas, N. Mex.

Leader

Robt. E. Wilkinson, U.S. Agricultural Research Service, Crops Research Division.

\section{Description}

Greenhouse-grown saltcedar is treated with a concentration series of various herbicides and (or) additives for herbicidal effectiveness or enhancement of herbicidal effectiveness. Evaluations of results after 8 weeks are corrected for the condition of the plant at time of treatment and (or) carrier effects.

Status

The study was initiated in 1963 and will be continued for an indefinite period.

Results

4-amino-3, 5, 6-trichloropicolinic acid was shown to be more effective than 2-(2, 4, 5trichlorophenoxy) propionic acid (Silvex) in greenhouse tests.

\section{Publications}

Articles in a technical journal as justified by significant results.

$$
\text { N. Mex-15 }
$$

Title

Correlation of the growth and physiological responses of saltcedar (Tamarix pentandra Pall.) to variations in photoperiod.
Agencies

U.S. Agricultural Research Service, Crops Research Division, in cooperation with the New Mexico Agricultural Experiment Station, Middle Rio Grande Branch Station, Los Lunas, N. Mex.

\section{Leader}

Robt. E. Wilkinson, U.S. Agricultural Research Service, Crops Research Division.

\section{Description}

Cuttings are grown on a mist bed for 8 hours during the day and in growth chambers during the night. Lights in the growth chambers are controlled by time clocks. Total hours of light are 11,14, and $8+1$ hours.

Status

Experiment initiated in 1963 and will be continued at least through 1964 .

Results

Vegetative growth of saltcedar in New Mexico appears to be much greater at the 14-hour photoperiod. Other primary or secondary photoperiod responses have been observed.

\section{Publications}

Technical publications at the completion of the study.

\author{
UTAH \\ Utah-1 \\ (21, Circ. 413)
}

Title

Utah phreatophyte survey.

\section{Agencies}

Utah State Engineer, with assistance by individuals from several State and Federal Agencies.

Leader

R. Keith Higginson, Utah State Engineer's Office.

\section{Description}

The State has been divided into hydrologic units, and each member of the survey group 
is responsible for the development of new data within his unit. Reconnaissance surveys will be made of the entire State to determine the location and density of phreatophytes and their effect upon the State's water supplies.

Status

Inactive.

Results

The parts of the State covered show a total of 700,000 acres covered by phreatophytic vegetation of various species and densities. This includes 6,000 acres of saltcedar which has been reported as far north as the Provo Bay area.

Publication

Progress report August 1958.

Utah-2

(22, Circ. 413)

Title

Consumptive use of water by native vegetation and irrigated crops in the Virgin River area of Utah.

\section{Agencies}

Utah Agricultural Experiment Station; U.S. Agricultural Research Service, Soil and Water Conservation Branch, Western Soil and Water Management Section; Utah Water and Power Board; Utah State Engineer.

\section{Leaders}

Wayne D. Criddle, Utah State Engineer's Office, and Jay M. Bagley, Utah Agricultural Experiment Station.

\section{Description}

Several types of phreatophytes were grown in tanks at an experimental site near the Virgin River. Measurements were made of the rates of water consumption by the vegetation within the tanks. These measurements were compared with water-table fluctuations and with potential evapotranspiration as indicated by data from atmometers. Data were also obtained on rates of consumptive use by irrigated crops in the area. The project began in 1955, and the fieldwork was completed in 1957.

\section{Status}

Completed.
Results

Results show the general range of use rates by irrigated crops and native vegetation.

\section{Publication}

Draft copies of the final report are available at the oifice of the Utah State Engineer and at the Utah State University.

\section{Utah-3}

Title

The water resources of Salt Lake County, Utah.

\section{Agencies}

U.S. Geological Survey and Utah State Engineer.

Leaders

W. V. Iorns and R. W. Mower, U.S. Geological Survey, and C. A. Horr, Utah State Engineer's Office.

\section{Description}

Many thousands of acres of phreatophytes in the lowlands around the southern end of Great Salt Lake and on the flood plains of the Jordan River and the lower reaches of tributaries consume several tens of thousands of acre-feet of ground water that may be put to higher use by man. The present study of the water resources of Salt Lake County will include a determination of the consumptive use by phreatophytes, as well as by irrigated crops to help estimate the perennial water supply of the county. The principal phreatophytes around the Great Salt Lake are greasewood, saltgrass, and pickleweed; and along the streams they are principally sedges and rushes. There are a few thickets and individual saltcedar plants throughout the valley; however, they are not a problem except that they present a threat to the infestation of all the lowlands and stream channels in the county.

Several weather stations have been established in the county, data from which are to be used in determining consumptive use by phreatophytes. The species, areal extent, and densities of phreatophytes will be mapped. 
Status

Study began July 1963 and will run through June 1968. Early stages of basic-data collection period.

Results

No results to report as of July 1, 1964. Publications

Final report to be one of U.S. Geological Survey series of reports. Progress and journal reports may be published in applicable media.

\section{WYOMING \\ Wyo- 1 \\ (23, Circ. 413)}

Title

Chemical control of saltcedar.

Agencies

U.S. Agricultural Research Service, U.S. Bureau of Reclamation Region 6, and Wyoming Agricultural Experiment Station, cooperating.

\section{Leaders}

R. D. Comes and F. L. Timmons, U.S. Agricultural Research Service.

\section{Description}

Basal applications of butoxyethanol esters of 2, 4-D and 2, 4, 5-T and a 50-50 mixture of the two were made on mature saltcedar at concentrations of 2 and 8 percent in diesel oil at spring-dormant, summer, and falldormant stages of growth in 1956 and 1957. All treatments were replicated three times.

Another experiment was begun in April 1958 comparing basal applications of butoxyethanol ester of 2, 4-D at concentrations of $0.5,1.0$, and 2.0 percent with broadcast applications of fenuron pellets at 10, 20, and 40 pounds active ingredient per acre and of monuron at 20 pounds active ingredient per acre.

\section{Status}

This study, initiated in 1956, has been completed except for final observations of results in Summer 1964 and preparation of a manuscript for a final publication.
Results

The basal applications of 2, 4-D and 2, 4, 5-T made at full-leaf stage in 1956 gave 100percent kill of saltcedar. Basal applications at the fall-dormant and spring-dormant stages were less effective, the survival being 18 to 23 percent for the 2-percent concentration and 4.5 to 10 percent for the 8-percent concentration. Treatments made in April 1958 showed complete defoliation by all rates of fenuron and monuron and complete kill by all rates of basally applied 2, 4-D. Some regrowth from saltcedar crowns developed in plots treated at the lowest concentration of 0.5 -percent 2, 4-D.

Publications

Comparison of different methods of applying fenuron pellets for control of mature saltcedar, by R.D. Comes and F.L. Timmons, in Research Prog. Rept., Western Weed Control Conf., Salt Lake City, Utah, March 2527, 1964.

Research in control of phreatophytes, by F. L. Timmons, unpub. paper presented at Soil Conserv. Service Hydraulic Engineers mtg., New York City, August 12-16, 1963. [Mimeo. copies available from the author.]

Chemical control of saltcedar, by F. L. Timmons and L. W. Weldon, in Research Prog. Rept., Western Weed Control Conf., Spokane, Washington, March 18-20, 1958: p. 46.

$$
\begin{gathered}
\text { Wyo-2 } \\
\text { (24, Circ. } 413)
\end{gathered}
$$

Title

Ecologic study of saltcedar.

\section{Agencies}

U.S. Agricultural Research Service, U.S. Bureau of Reclamation, and Wyoming Agricultural Experiment Station, cooperating.

\section{Leaders}

R. D. Comes and F. L. Timmons, U.S. Agricultural Research Service.

\section{Description}

Eight plots, most of them 33 feet by 66 feet, were permanently staked out in May 1956 in typical saltcedar infestations ranging in age and size from seedlings less than 1 inch tall to mature trees 10 feet tall. Four 
additional plots were established in 1957 and 1958 in new infestations or on areas subject to invasion by saltcedar. The 12 plots are distributed in representative situations along 10 miles of Five Mile Creek from its juncture with Boysen Reservoir in central Wyoming. A total of 33 individual saltcedar plants within these plots was labeled for detailed study.

In May of each year measurements are made on number of living saltcedar plants per plot, number of shoots per plant, range and average in height of plants, range and average diameter of shoots, distance from edge of Five Mile Creek, height of plot above water surface in Five Mile Creek, and other ecologic measurements. A picture of each plot is taken from the same location in June of each year.

Supplementary phenological observations are made each year on dates of first leaf, full leaf, first bloom, full bloom, first seed maturity, and fall leaf drop. Amount of seed produced and seed viability are also determined.

\section{Status}

This study, initiated in 1956, has been completed except for final observations of results in the spring of 1964 and preparation of a manuscript for a final publication on salt- cedar in Wyoming, ecology, distribution, and control.

Results

\section{Publication}

Ecological studies of saltcedar, by F. L. Timmons and L. W. Weldon, in Res. Prog. Rept., Western Weed Control Conf., Spokane, Washington, March 18-20, 1958: p. 47-48.

\section{REFERENCES CITED}

Horton, J. S., Robinson, T. W., and McDonald, H. R., 1964, Guide for surveying phreatophyte vegetation: U.S. Dept. of Agriculture, Forest Service, Agriculture Handb. 266, 37 p., illus.

Pacific Southwest Inter-Agency Committee, 1961, Minutes of the $6 i-4$ meeting, duplicated report, p. 4-58.

Robinson, T. W., 1952, Phreatophytes and their relation to water in Western United States: Am. Geophys. Union Trans., v. 33, no. 1 , p. 57-61.

1958, Phreatophytes: U.S. Geol. Survey

Water-Supply Paper 1423, p. 24, 25.

1959, Phreatophyte research in Western

United States, October 1958 to March 1959:

U.S. Geol. Survey Circ. 413. 